\title{
Credit Flows to Pakistan's Manufacturing SME Sector
}

\author{
Imran Ahmad* and Karim Alam**
}

\begin{abstract}
This paper profiles the flow of credit to manufacturing SMEs and their subsectors in Pakistan. We discuss the challenges confronting the SME sector as well as the role of the central bank in this context. Based on the literature and data available, we find that the flow of financing to the manufacturing sector witnessed a gradual and steady increase in absolute terms, although its share of total industry credit declined sharply over a nine-year period. Financing to manufacturing SMEs initially declined and then increased over a period of six years.
\end{abstract}

Keywords: Credit, manufacturing, small \& medium enterprise (SME), Pakistan.

JEL classification: E51, L60.

\section{Introduction}

The manufacturing sector is a vital sector of the economy as well as a catalyst for growth. Countries such as China and Singapore have witnessed tremendous growth driven by the manufacturing sector (Anwar, 2008). The sector is not homogeneous; rather, it comprises a number of subsectors, each with diverse needs and characteristics. Nevertheless, access to finance remains a common constraint among enterprises.

In Pakistan, manufacturing is the economy's third largest sector, contributing 13.5 percent to GDP and 14.1 percent to total employment. Large-scale manufacturing contributes around 10.9 percent as against small-scale manufacturing at 1.7 percent of total GDP (Pakistan, Ministry of Finance, 2014). The average flow of outstanding credit from the banking industry was PRs 1,385.5 billion over a period of nine years (2006-14), with a standard deviation of PRs 229.5 billion. The share of financing available to the manufacturing sector was approximately 50

\footnotetext{
* Additional Director, Infrastructure, Housing and SME Finance Department, State Bank of Pakistan. ** Deputy Director, Infrastructure, Housing and SME Finance Department, State Bank of Pakistan. The views expressed in this paper are those of the authors and do not reflect the views of the State Bank of Pakistan.
} 
percent of total private sector credit ${ }^{1}$ or 16 percent of the financial sector's total outstanding credit. However, financing is not well diversified and remains concentrated in specific subsectors (Table 1). Beck, DemirgüçKunt, and Pería (2011) find similar results.

Access to finance and an efficient financial system are key to economic growth and development (see Nasr, 2008). Limited access to finance is often a constraint to industrial growth, especially for the small and medium enterprise (SME) sector. Therefore, it is useful to identify its importance as well as to understand whether the formal sector is able to meet its financing needs.

Much of the literature, as discussed below, gives special importance to the role of financial organizations in economic growth, especially in the banking sector. However, there are conflicting theories with regard to its role in affecting the size and growth of industries. Based on panel data estimations, Hoxha (2013) finds that industries' performance depends on external finance and that competition within the banking sector can harm industries that need external financing. Anwar (2008) argues that factors such as foreign investment and human capital development are also key to manufacturing sector growth, while diversification, increased spending on research and development, and improved education are critical for sustainable future growth.

Finance also promotes capital accumulation and enables optimal allocation. The traditional literature ascribes two distinct roles to the finance-growth nexus: (i) promoting growth and development, and (ii) increasing the demand for financial services as a result of economic growth (see Stolbov, 2012).

\section{Credit Flows to Pakistan's Manufacturing Sector}

This section discusses financing trends in the sector based on the total flow of industry credit, the share of manufacturing in total credit, and credit flows to the manufacturing sector.

Figure 1 shows credit flows to the manufacturing sector vis-à-vis overall industry credit. The period 2006-14 registered a significant and steady growth rate of 75 percent in overall credit flows to private sector businesses. The manufacturing sector accounts equally impressively for a 74 percent growth rate in this period. Its average annual growth recorded

\footnotetext{
${ }^{1}$ Investment in private sector securities and shares, and loans to the private sector.
} 
is 7 percent as opposed to 18 percent for total industry credit. The share of the manufacturing sector in total industry credit declined sharply from 35 percent in 2006 to 16 percent in 2014.

Figure 1: Flows to manufacturing sector and its share (PRs bn)

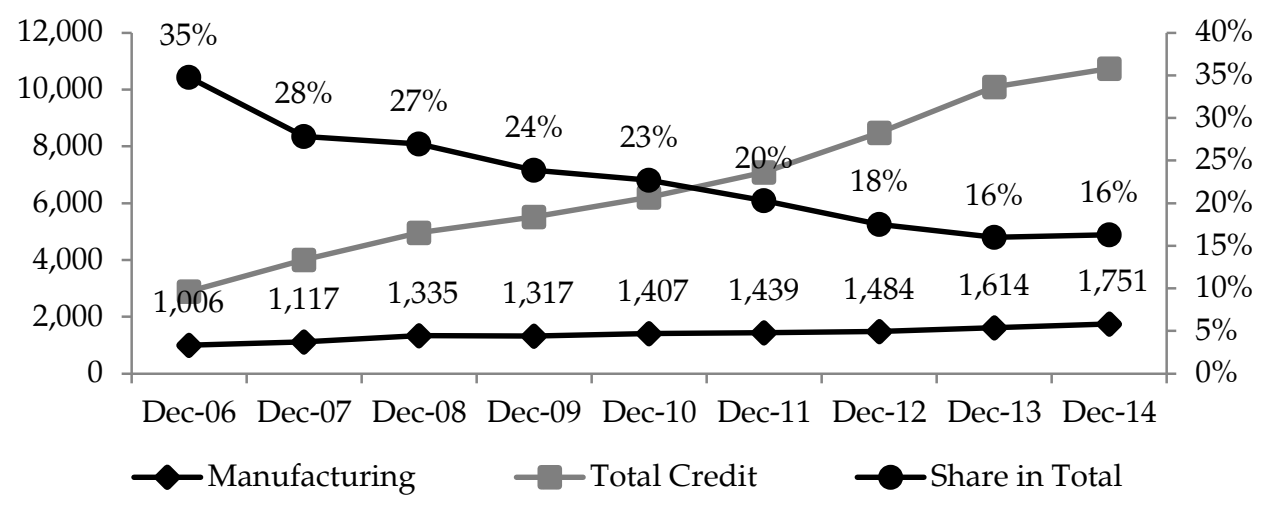

Source: State Bank of Pakistan.

Table 1 lists key subsectors that account for the highest flows of credit. The lion's share of 35 percent goes to textiles, followed by food products and beverages at 25 percent. Their respective average flows recorded over the period 2006 to 2014 are PRs 551.7 billion and PRs 253.7 billion, respectively. The table also shows that financing is concentrated in only a few manufacturing subsectors, thus resulting in less diversity as far as financing to these sectors is concerned. It is important to mention here that the textiles sector includes subsectors such as spinning, weaving, and finishing; made-up textile articles; knitwear; carpets and rugs; and other textiles not elsewhere classified. However, of the total financing to the textiles sector, the largest share of 79 percent is channeled into the spinning, weaving, and finishing subsector. 
Table 1: Share of top ten manufacturing sectors vs. average financing

\begin{tabular}{lcc}
\hline Subsector & $\begin{array}{c}\text { \% Share of total O/S } \\
\text { to manufacturing } \\
\text { sector }\end{array}$ & $\begin{array}{c}\text { Average financing } \\
\text { 2006-14 } \\
\text { (PRs bn) }\end{array}$ \\
\hline Textiles & 35 & 551.7 \\
Food products and beverages & 25 & 253.7 \\
Chemicals and chemical products & 11 & 146.9 \\
Basic metals & 5 & 50.2 \\
Other nonmetallic mineral products & 3 & 86.8 \\
Apparel, readymade garments & 3 & 48.2 \\
Coke, refined petroleum products & 3 & 31.7 \\
Electrical machinery and apparatus & 3 & 43.0 \\
Paper, paperboard and products & 2 & 24.4 \\
Machinery and equipment & 2 & 20.6 \\
\hline
\end{tabular}

Source: State Bank of Pakistan.

Similar trends are apparent in other emerging economies such as India and Singapore, where certain subsectors attract the largest volume of financing. A likely explanation for this is that industrial sectors tend not to be homogenous. Moreover, the enterprise-level reality may differ from its sectoral classification (Kirner, Kinkel, \& Jaeger, 2009).

\section{SME Financing in Pakistan}

SMEs constitute over 93 percent of an estimated 3.2 million business enterprises in the country (Beck \& Demirgüç-Kunt, 2006). In overall macroeconomic terms, SMEs (defined by the number of employees) contribute 30 percent to the national GDP and 25 percent to total export earnings, indicating why the sector is economically significant. SMEs can be categorized broadly as services, manufacturing, or trade, of which we look specifically at manufacturing units.

\subsection{Credit Flows to Manufacturing SMEs}

One of the key roles of the business finance market is to fund SMEs (see Makena, Kubaison, \& Njati, 2014), given that the development of this sector is considered a core element of fostering economic growth and generating employment. Hallberg (2000) argues that governments should promote SMEs because they account for a large share of the total firms in an economy, can generate significant employment, and as "the emerging private sector in poor countries," they form a "base for private sector-led growth." Nonetheless, SMEs often find it difficult to access finance through the formal sector. 
Manufacturing SMEs in particular contribute significantly to economic growth (see Terziovski, 2010). Beck, Demirgüç-Kunt, Laeven, and Levine (2008) use cross-country and cross-industry data to establish that financial development has a larger positive effect on the growth of industries that comprise small firms versus those that comprise large firms.

Figure 2 compares financing trends in the SME sector vis-à-vis manufacturing SMEs. Growth in credit flows to both manufacturing SMEs and the SME sector as a whole recorded a rising trend after December 2012. The corresponding amounts of average financing received are PRs 121 billion and PRs 301 billion during 2009-14, with standard deviations of 45 and 110, respectively.

Figure 2: Credit flows to manufacturing SMEs vs. all SMEs (PRs bn)

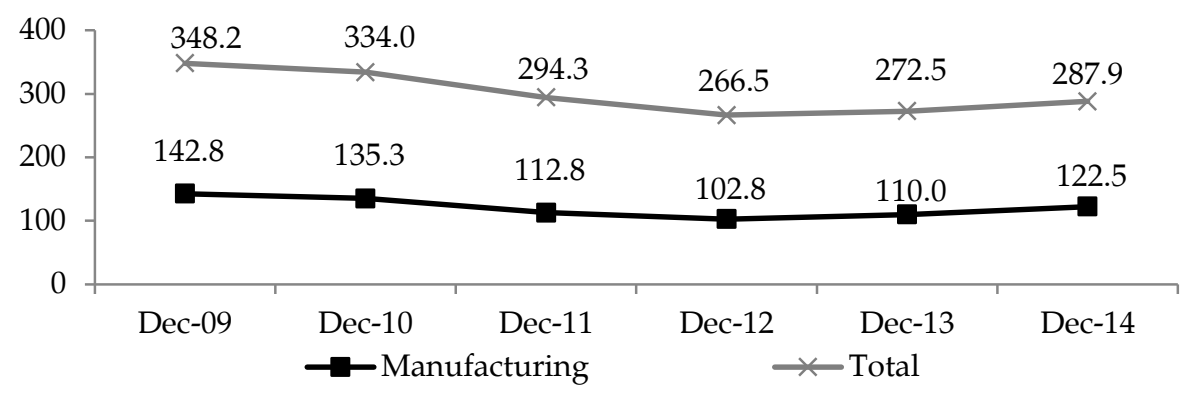

Source: State Bank of Pakistan.

Figure 3 compares sectoral trends in financing at a macro-level among the three SME subsectors (trading, manufacturing, and services). Manufacturing SMEs initially show a declining trend up until December 2012, after which they indicate a positive growth trend. Financing to the services subsector follows a similar trajectory, but the growth is more prominent for manufacturing SMEs.

Figure 3: Financing to SMEs, by subsector (PRs bn)

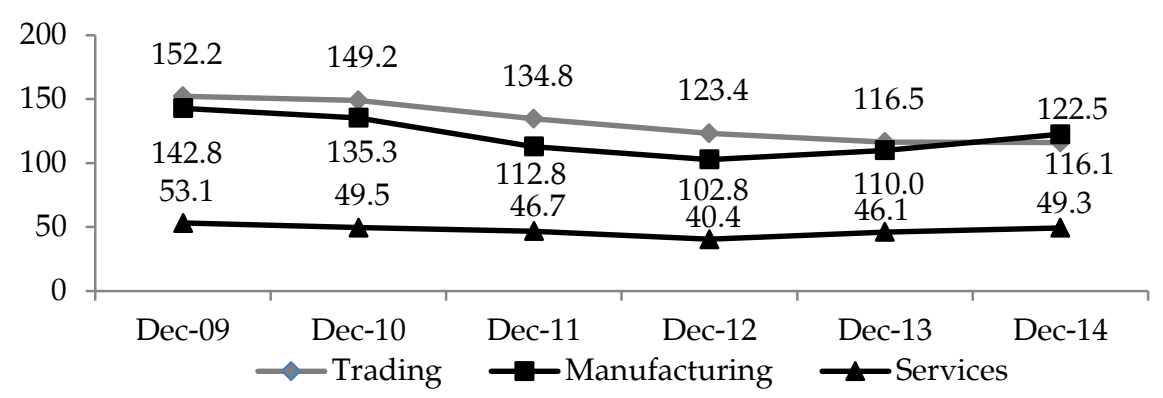

Source: State Bank of Pakistan. 
At the end of December 2014, trading, manufacturing, and services accounted for 40.3, 42.5, and 17.1 percent, respectively, of the total financing to the SME sector. The share of manufacturing SMEs rose more sharply than that of trading SMEs; the share of the services sector declined from 2009 onward.

\subsection{Credit Flows to Manufacturing SME Subsectors}

Table 2 shows that, like the overall manufacturing sector, financing to manufacturing SMEs is highly concentrated in a few subsectors, with textiles and food products and beverages accounting for 22 and 37 percent, respectively.

Table 2: Share of key SME manufacturing subsectors

\begin{tabular}{lcc}
\hline & \multicolumn{2}{c}{ \% Share of financing } \\
\cline { 2 - 3 } Sector & To manuf. SMEs & To all SMEs \\
\hline Food products and beverages & 22 & 17 \\
Textiles & 6 & 22 \\
Chemicals and chemical products & 4 & 6 \\
Apparel, readymade garments & 4 & 2 \\
Basic metals & 2 & 2 \\
Tanning and dressing of leather; & & 1 \\
manufacture of luggage and footwear & 2 & \\
Rubber and plastic products & 2 & 1 \\
Paper, paperboard and products & 2 & 1 \\
Fabricated metal products & 2 & 1 \\
Medical, precision and optical instruments; & & \\
watches and clocks & 2 & 1 \\
Other nonmetallic mineral products & 2 & 1 \\
Sports goods & & \\
\hline
\end{tabular}

Source: State Bank of Pakistan.

\subsection{Key Challenges in SME Financing}

SMEs face a number of financial and institutional obstacles to procuring credit compared to larger enterprises. These constraints are all the more challenging in developing countries whose financial systems are more likely to be weak (Beck \& Demirgüç-Kunt, 2006). Based on our interaction and discussions with various market actors, we have identified the following key challenges on the supply side: 
- Lack of innovative financial products

- High investment in government securities

- High transactional cost of serving SMEs

- Banks' risk-averse approach

Demand-side challenges include the following:

- Lack of satisfactory business plans, accounting, and other information

- Insufficient assets for use as security

- Lack of financial awareness of different banking services

- Limited new or innovative approaches to addressing SME clients

In addition to these factors, business activity in Pakistan is constrained by energy shortages and by law and order or security issues (State Bank of Pakistan, 2014, 2015).

\section{The Central Bank's Role in SME Financing}

Central banks perform both conventional and nontraditional functions. In the context of promoting SME credit, Boldbaatar (2005) suggests three key areas for central bank intervention: (i) financial market infrastructure development, (ii) enhancing the availability of credit information, and (iii) swift and secure banking for small borrowers. Some of the measures taken by the State Bank of Pakistan (SBP) to improve the SME lending market are as follows (State Bank of Pakistan, 2013):

- A comprehensive regulatory framework to enable SME financing exists. In 2013, the regulations were revised, giving more focus to small enterprises as well as lending incentives for banks.

- The SBP has established a dedicated e-Credit Information Bureau.

- The SBP is facilitating the establishment of a secure transaction registry, which will be instrumental in lending to small borrowers.

As a regulator of the country's banking industry, the SBP should take the following measures to bring more SMEs into the credit lending market and improve their access to finance:

- Improve the regulatory environment based on market dynamics 
- Design and implement capacity-building events, workshops, and seminars to improve SME clients' financial literacy

- Assign market-based indicative targets for SME financing to banks and development finance institutions

- Explore the role of nonbank financial companies as business facilitators

- Introduce venture capital for start-up businesses

- Strengthen and expand the scope and role of the e-Credit Information Bureau.

The SBP has also undertaken a number of market segmentation studies (which are available on its website); this exercise should be continued to cover more sectors.

\section{Conclusion}

We have examined the flow of credit to Pakistan's manufacturing sector, focusing particularly on manufacturing SMEs. The data suggest that, in absolute terms, credit flows to the manufacturing sector grew steadily between December 2006 and December 2014. However, its share of total industry credit ${ }^{2}$ declined drastically from 35 to 16 percent during this period. Moreover, the flow of credit is concentrated in a few subsectors both in the manufacturing sector overall as well as among manufacturing SMEs. This reflects the low level of diversification where financing is concerned.

Having identified several reasons for this low level of financing, we examine the role of the central bank and suggest measures it could take to enhance the lending market for SMEs. This analysis, however, presents a macro-picture of the manufacturing sector and key subsectors, and does not consider regional or sectoral dynamics and corresponding credit needs. The natural progression of this work would be to identify the financing gap for the overall manufacturing sector as well as for manufacturing SMEs in particular. This would help assess the needs of both sectors and measures to ensure the appropriate supply of credit is made available.

\footnotetext{
${ }^{2}$ Total credit to the government and nongovernment sectors.
} 


\section{References}

Anwar, S. (2008). Foreign investment, human capital and manufacturing sector growth in Singapore. Journal of Policy Modeling, 30(3), 447-453.

Beck, T., \& Demirgüç-Kunt, A. (2006). Small and medium-size enterprises: Access to finance as a growth constraint. Journal of Banking and Finance, 30(11), 2931-2943.

Beck, T., Demirgüç-Kunt, A., Laeven, L., \& Levine, R. (2008). Finance, firm size, and growth. Journal of Money, Credit and Banking, 40(7), 1379-1405.

Beck, T., Demirgüç-Kunt, A., \& Pería, M. S. M. (2011). Bank financing for SMEs: Evidence across countries and bank ownership types. Journal of Financial Services Research, 39(1), 35-54.

Boldbaatar, D. (2005). Role of central banks in promoting small and mediumscale enterprises (Research Studies No. 60). Kuala Lumpur: South East Asian Central Banks Research and Training Centre.

Hallberg, K. (2000). A market-oriented strategy for small and medium-scale enterprises (Report No. IFD40). Washington, DC: World Bank.

Hoxha, I. (2013). The market structure of the banking sector and financially dependent manufacturing sectors. International Review of Economics and Finance, 27, 432-444.

Kirner, E., Kinkel, S., \& Jaeger, A. (2009). Innovation paths and the innovation performance of low-technology firms: An empirical analysis of German industry. Research Policy, 38(3), 447-458.

Makena, P., Kubaison, S. T., \& Njati, C. I. (2014). Challenges facing women entrepreneurs in accessing business finance in Kenya: Case of Ruiru Township, Kiambu County. IOSR Journal of Business and Management, 16(4), 83-91.

Nasr, S. (2008). Access to finance and economic growth in Egypt. Washington, DC: World Bank.

Pakistan, Ministry of Finance. (2014). Pakistan economic survey 2013-14. Retrieved from http://www.finance.gov.pk/survey_1314.html. 
State Bank of Pakistan. (2013). Development finance review, December 2013. Retrieved from http://www.sbp.org.pk/SME/PDF/DFG/ 2013/DF Review-Dec 13.pdf

State Bank of Pakistan. (2014). Annual report 2013-14. Retrieved from http:/ / www.sbp.org.pk/reports/annual/arFY14/Anul-indexeng-14.htm

State Bank of Pakistan. (2015). The state of Pakistan's economy: Second quarterly report for the year 2014-15. Retrieved from http://www.sbp.org.pk/reports/quarterly/fy15/Second/Compl ete.pdf

Stolbov, M. (2012). The finance-growth nexus revisited: From origins to a modern theoretical landscape (Economics Discussion Paper No. 201245). Kiel: Kiel Institute for the World Economy.

Terziovski, M. (2010). Innovation practice and its performance implications in small and medium enterprises (SMEs) in the manufacturing sector: A resource-based view. Strategic Management Journal, 31(8), 892-902. 